\title{
WYBRANE PROBLEMY MIĘDZYCZASOWE W PRAWIE PODATKOWYM W KONTEKŚCIE WSKAZAŃ KATOLICKIEJ MYŚLI SPOŁECZNEJ
}

\section{Wstęp}

Przedmiotem poniższych rozważań jest ukazanie wybranych aspektów zmian prawa podatkowego, istotnych z punktu widzenia podstawowych wskazań katolickiej myśli społecznej. Powinno to choć częściowo przyczynić się do uzyskania rzetelnej odpowiedzi na pytanie: na ile państwo służy podatnikowi, a na ile podatnik jest bezwolnym obiektem polityki państwa w obszarze metodyki nowelizacji prawa podatkowego.

Celem niniejszego artykułu nie jest omawianie szczegółowych rozwiązań prawa pozytywnego ${ }^{1}$. Intencją autora jest raczej przypomnienie wybranych reguł stanowienia i stosowania prawa na tle refleksji obecnej na gruncie katolickiej myśli społecznej. W pewnym sensie jest to zatem bardziej perspektywa filozofii prawa niż jego dogmatyki. Tym samym chodzi o zestawienie zasad, nie zaś analizę obowiązujących tekstów prawnych.

\footnotetext{
* Dr nauk prawnych, mgr teologii, doktorant Papieskiego Wydziału Teologicznego we Wrocławiu; e-mail: obywatelak2030@gmail.com, https:// orcid.org/0000-0001-9278-7522.

1 Stąd pominięcie $\mathrm{w}$ tekście odesłań do konkretnych regulacji podatkowych. $\mathrm{W}$ istocie każda nowelizacja prawa niesie ze sobą zagadnienie intertemporalne (mniej albo bardziej skomplikowane). Wybór na potrzeby niniejszej analizy niektórych z nich byłby jedynie rodzajem egzemplifikacji, mogącej zaburzyć tok rozważań na płaszczyźnie zasad. Nieco inny charakter mają regulacje, których zadaniem jest utrwalenie przyjętych wcześniej założeń prawodawczych. Są one jednak zakorzenione w tychże zasadach, zatem bezpośrednie przywołanie tych ostatnich pozwala odnieść się do najtrwalszych fundamentów przejściowego prawa podatkowego.
} 
Jest to powodowane co najmniej dwoma względami. Pierwszy wynika z istotnej zmienności przepisów prawnych, drugi natomiast dotyczy specyfiki katolickiej nauki społecznej, zorientowanej, w swej kluczowej części, na formułowanie zasad fundamentalnych i ponadczasowych².

\section{Ogólne uwagi w kwestiach intertemporalnych}

W zakresie stosunków społecznych zwiększone natężenie zmian można zaobserwować w obszarze regulowanym normami prawnymi. Związane z tym problemy potęgują się, gdy skutki regulacji prawnych dotyczą bezpośrednio interesów majątkowych obywateli. Intensyfikacji wątpliwości sprzyja również powszechność danego rodzaju stosunków prawnych oraz ich rozpiętość w czasie. Dodatkowy aspekt stanowi element wolicyjny i związana z nim możliwość (lub nie) zmiany przez jednostkę skutków wcześniej podjętych decyzji. Pod względem natężenia trudnych do odwrócenia skutków tych decyzji prawo podatkowe jest szczególnie relewantne. Niebezpieczeństwo szkodliwości społecznej nieodpowiedzialnej nowelizacji prawa jest podwójne. Obok zagrożeń treściowych, które z natury regulacji podatkowych są wyposażone w bezwzględne imperium państwa, niesie bowiem dodatkowo ryzyko proceduralno-temporalne.

W obszarze problemów związanych ze stanowieniem i stosowaniem właściwych regulacji w sytuacji zmiany prawa nie ma pełnej jednoznaczności terminologicznej. W tym kontekście wspomina się o regulacjach intertemporalnych (międzyczasowych), stosowaniu lub obowiązywaniu nowego bądź starego prawa, a także działaniu prawa w czasie (dalszym lub bezpośrednim) ${ }^{3}$. Analityczne omawianie tej problematyki przekraczałoby zdecydowanie ramy niniejszego opracowania. Na jego potrzeby

2 Wspomniane zasady są wyrazem prawdy o człowieku. Mają one charakter ogólny i dotyczą rzeczywistości społecznej jako całości: poczynając od stosunków międzyludzkich, po relacje polityczne, ekonomiczne i prawne, por. Papieska Rada Iustitia et Pax, Kompendium Nauki Społecznej Kościoła, Kielce 2005, nr 161.

3 Rację ma J. Stelmach, pisząc, że „problematyka związana z obowiązywaniem prawa należy do najbardziej skomplikowanych i spornych kwestii całego prawoznawstwa”. „Prawo [...] obowiązuje z racji swojego istnienia, bo po prostu jest prawem. Ta właśnie tautologia jest elementarnym składnikiem prawniczego myślenia, będąc wyrazem naszych apriorycznych wyobrażeń na temat prawa", por. J. Stelmach, Obowiązywanie prawa 
wystarczy jedynie zasygnalizować podstawowe dylematy terminologiczne obecne w obszarze problematyki tranzytoryjnej, z dalszym odesłaniem do literatury przedmiotu ${ }^{4}$. Pozwoli to na naszkicowanie obszaru odniesienia prowadzonej dalej refleksji w postaci szeroko rozumianej sytuacji intertemporalnej w prawie podatkowym.

w sensie absolutnym i relatywnym, w: Teoria prawa. Filozofia prawa. Wspótczesne prawo i prawoznawstwo, red. M. Kocoł, W. Lang, Torun 1998, s. 315-316.

4 Por. np. A. Aarnio, O obowiazywaniu, skuteczności i akceptowalności norm prawnych, Acta Universitatis Lodziensis. Folia Iuridica 1987, t. 32; A.F. Ballard, Retroactive Federal Taxation, Harvard Law Review 1935, nr 48; D. Bąbiak-Kowalska, w: Prawo intertemporalne w orzecznictwie Trybunatu Konstytucyjnego i Sądu Najwyższego, red. E. Łętowska, K. Osajda, Warszawa 2008; T. Bonneau, La Cour de Cassation et l'application de la loi dans le temps, Paris 1990; Z. Duniewska, Instytucja vacatio legis w prawie administracyjnym, Studia Prawno-Ekonomiczne 1997, t. 56; L. Etel, Wejście w życie uchwat podatkowych - wybrane problemy, w: Wkregu prawa podatkowego i finansów publicznych. Ksiegga dedykowana Profesorowi Cezaremu Kosikowskiemu w 40-lecie pracy naukowej, red. H. Dzwonkowski, J. Głuchowski, A. Pomorska, J. Szołno-Koguc, Lublin 2005; P.J. Grabowski, W sprawie zakresu temporalnego obowiazywania prawa, Państwo i Prawo 2004, z. 4; P. Grabowski, M. Herman, O normatywnym charakterze przepisów o wejściu w życie, Państwo i Prawo 2006, z. 9; H.L. Gray, Carlton v. United States: An Analysis of Retroactive Tax Legislation, Stetson Law Review 1995, t. 24, nr 3; J. Heron, Principes du droit transitoire, Dalloz 1996; A. Huchla, Nieprzestrzeganie "zasad podatkowych" w procesie tworzenia polskiego prawa podatkowego, w: Prawo finansowe i nauka prawa finansowego na przełomie wieków, red. A. Kostecki, Kraków 2000; M. Kamiński, Prawo administracyjne intertemporalne, Warszawa 2011; K. Karasiewicz, w: Prawo intertemporalne...; M. Kłoda, Wybrane zagadnienia intertemporalne Kodeksu spótek handlowych Cz. I, Monitor Prawniczy 2001, nr 8; P. Kurowska, Problemy interpretacyjne w aspekcie tworzenia prawa podatkowego, Kwartalnik Prawa Podatkowego 2005, nr 2; J.G. Laitos, Legislative Retroactivity, Urban Law Annual; Journal of Urban and Contemporary Law 1997, t. 52; W. Lang, Obowiązywanie normy prawnej w czasie w świetle logiki norm, Zeszyty Naukowe Uniwersytetu Jagiellońskiego. Prace Prawnicze 1960, z. 7; E. Łętowska, Polityczne aspekty prawa intertemporalnego, w: Państwo. Prawo. Obywatel. Zbiór studiów dla uczczenia 60-lecia urodzin i 40-lecia pracy naukowej prof. Adama Łopatki, red. J. Łętowski, W. Sokolewicz, Wrocław 1989; J. Małecki, Kwestie intertemporalne w prawie podatkowym, w: Regulacje prawno-podatkowe i rozwiazania finansowe Pro publico bono. Ksiegga Jubileuszowa Profesora Jana Głuchowskiego, red. J. Głuchowski, Torun 2002; J. Mordwiłko, K. Osajda, w: Prawo intertemporalne...; Problematyka intertemporalna w prawie. Zagadnienia podstawowe. Rozstrzygnięcia intertemporalne. Geneza i funkcje, red. J. Mikołajewicz, Warszawa 2015; B. Nita, A. Światłowski, O retroaktywności prawa karnego (uwagi polemiczne na tle artykułu W. Wróbla), Przegląd Sądowy 1994, nr 3; T. Pietrzykowski, Temporalny zakres obowiązywania prawa, Państwo i Prawo 2003, z. 4; P. Roubier, Le Droit Transitoire (conflits des lois dans le temps), Paris 1960; B. Smith, Retroactive Laws and Vested Rights, Texas Law Review 1927, t. 5; S. Wronkowska, O stanowieniu i ogłaszaniu prawa oraz kulturze prawnej, Państwo i Prawo 2007, z. 4; M. Zirk-Sadowski, Problem nowości normatywnej, Studia Prawno-Ekonomiczne 1979, t. 22. 
Przez stosowanie prawa najczęściej rozumie się zespół czynności prowadzących do wydania indywidualnej decyzji ustalającej skutki prawne określonego faktu prawnego ${ }^{5}$. W innym ujęciu o stosowaniu prawa można mówić, gdy podmiot czyni użytek z kompetencji przyznanej mu przez określoną normę prawną ${ }^{6}$. W ocenie J. Brolika „istotnym i zasadniczym elementem procesu stosowania prawa jest ustalenie i ocena, które z norm należących do danego porządku prawnego są bądź mogą się okazać adekwatne do załatwienia sprawy"7. Z kolei zdaniem W. Łączkowskiego stosowanie prawa polega na „dokładnym odczytaniu i wykonaniu normy prawnej" ${ }^{8}$. W ujęciu międzyczasowym stosowanie prawa (norm, przepisów) należy dodatkowo odnieść do elementu czasu (rozważając jednocześnie relację derogacji i dalszego stosowania jej obiektu) oraz kwestii obowiązywania.

Prosta analiza języka prawnego i prawniczego wydaje się sugerować, że okres obowiązywania prawa w czasie obejmuje część wspólną zakresów czasu związanych z przynależnością przepisu do „aktualnego” systemu prawa oraz obowiązkiem jego stosowania9. W orzecznictwie Try-

5 Por. T. Pietrzykowski, Wsteczne działanie prawa i jego zakaz, Kraków 2004, s. 29.

6 Por. Z. Ziembiński, Teoria prawa, Warszawa-Poznań 1973, s. 117; zob. też P. Tuleja, Stosowanie Konstytucji RP w świetle zasady jej nadrzędności (wybrane problemy), Kraków 2003, s. 72. Zdaniem J. Wróblewskiego stosowanie prawa jest aktywnością polegającą na: a) wiążącym ustalaniu praw lub obowiązków osób lub stanu prawnego w decyzji stosowania prawa, b) wykorzystywaniu kompetencji do działań polegających na wydaniu określonego rodzaju decyzji, c) wykonywaniu uprawnień i spełnianiu obowiązków nałożonych przez reguły prawne, por. J. Wróblewski, Sądowe stosownie prawa, Warszawa 1988, s. 7-8; H. Rot, Elementy teorii prawa, Wrocław 1994, s. 225-226. Szerokim rozumieniem stosowania prawa posługuje się również K. Pałecki, por. tegoż, O zjawisku dylatacji mocy obowiązującej prawa, w: Prawo i ład społeczny. Księga Jubileuszowa dedykowana Profesor Annie Turskiej, red. G. Polkowska, Warszawa 2000, s. 31.

7 Por. J. Brolik, Wybrane zagadnienia przestrzegania prawa w procesie samoobliczenia podatku, w: Ius et lex. Księga Jubileuszowa Profesora Andrzeja Kabata, red. S. Pikulski i in., Olsztyn 2004, s. 65.

8 Por. W. Łączkowski, Wymiar sprawiedliwości a stosowanie prawa, w: Ius et lex. Księga jubileuszowa ku czci Profesora Adama Strzembosza, red. A. Dębiński, A. Grześkowiak, K. Wiak, Lublin 2002, s. 235.

9 Por. T. Pietrzykowski, Wsteczne dziatanie prawa..., s. 37-39. W tym kontekście w piśmiennictwie rozróżnia się niekiedy dwa kryteria ustalania zakresu czasowego obowiązywania przepisu: formalnym i materialnym, por. P. Radziewicz, Umarzanie postępowania przez Trybunat Konstytucyjny ze względu na utratę mocy obowiązującej przepisu przed wydaniem orzeczenia, Przegląd Sejmowy 2006, nr 2, s. 27. 
bunału Konstytucyjnego przyjęto jednak, że utrata mocy obowiązującej następuje dopiero $\mathrm{w}$ sytuacji, gdy dany przepis nie może być już zastosowany ${ }^{10}$. W tym ujęciu obowiązywanie sensu largo rozumiane jest jako sytuacja, gdy akt (nawet objęty derogacją) może być jednak zastosowany do jakiejkolwiek sytuacji z przeszłości, teraźniejszości lub przyszłości ${ }^{11}$. Oznacza to rozdział pojęciowy uchylenia przepisu i utraty przez niego mocy obowiązującej ${ }^{12}$. $\mathrm{Z}$ temporalnego punktu widzenia może to prowadzić do wyróżnienia obowiązywania przepisów w pełnym zakresie zastosowania (tj. od momentu wejścia przepisów w życie do chwili ich formalnej derogacji) oraz w ograniczonym zakresie zastosowania (w szczególności, choć nie tylko, po ich formalnym derogowaniu, jeśli na mocy reguł międzyczasowych znajdą one jeszcze zastosowanie do określonych sytuacji prawnych ${ }^{13}$. W tym ostatnim znaczeniu przepisy przejściowe stanowiłyby legitymację do przypisania określonym formułom tekstowym mocy wiążącej ${ }^{14}$.

10 Zob. orzeczenie TK z dnia 8 stycznia 1991 r., P 1/90, OTK ZU 1991, poz. 6. Szczególnie istotny był „argument odwołujący się do konieczności zagwarantowania przez Trybunał ochrony indywidualnych praw i wolności podmiotów [...]", por. P. Radziewicz, Umarzanie postępowania..., s. 18.

11 Por. orzeczenie TK z dnia 11 kwietnia 1994 r., K 10/93, OTK ZU 1994, poz. 7.

12 Taki punkt widzenia nawiązuje do rozróżnienia częściowego i całkowitego obowiązywania normy prawnej. To ostatnie miałoby miejsce jedynie w okresie pomiędzy wejściem w życie przepisu stanowiącego podstawę interpretacyjną tej normy a jego uchyleniem. W tym świetle definitywna utrata mocy obowiązującej przepisu następuje wtedy, gdy nie może być on w ogóle stosowany, por. uchwałę SN z dnia 30 maja 2003 r., III CZP 29/03, OSNC 2004, nr 4, poz. 50.

13 Chodzi zatem o odniesienie rozumienia mocy wiążącej normy prawnej do określonego zakresu jej zastosowania, por. J. Nowacki, Kryteria obowiązywania norm prawnych a wytyczne wymiaru sprawiedliwości i praktyki sądowej, Studia Prawno-Ekonomiczne 1974, t. 13, s. 36, 38 i 40. M. Kłoda pisze w podobnym kontekście o „okresie obowiązywania sensu stricto" oraz o "okresie przedłużonego obowiązywania”, zob. tegoż, Prawo międzyczasowe prywatne. Podstawowe zasady, Warszawa 2007, s. 67.

14 Dalszą sprawą byłoby zagadnienie, czy obowiązuje jedynie przepis przejściowy, czy też przepis ten wraz z regulacją, której dalsze stosowanie on zakłada. Przykładowo w nieco odmiennej sytuacji tzw. przywrócenia mocy obowiązującej uchylonym wcześniej przepisom, zdaniem S. Wronkowskiej, „to [...], że się prawodawca na dawne (uchylone) przepisy powołał, pełniło jedynie funkcję dogodnego skrótu" (tejże, O źródłach prawa i aktach normatywnych raz jeszcze, w: Prawo prywatne czasu przemian. Księga pamiątkowa dedykowana Profesorowi Stanistawowi Sołtysińskiemu, Poznań 2005, s. 134). 
Osobną sprawą jest łączenie przymiotu obowiązywania z normami, przepisami, aktami prawnymi bądź też prawem jako całością wiążących reguł postępowania ${ }^{15}$.

$Z$ definicją terminu „prawo intertemporalne" rzecz nie przedstawia się całkiem jednoznacznie. W polskiej literaturze można spotkać kilka podstawowych poglądów określających jego przedmiot ${ }^{16}$. Zgodnie z poglądem M. Sośniaka prawo intertemporalne należałoby definiować jako określony zbiór reguł (norm) rozstrzygających konflikty norm w czasie ${ }^{17}$. Inne ujęcie proponuje S. Grzybowski. Jego zdaniem prawo intertemporalne to zespół reguł (metanorm) wskazujących, w jakich przypadkach należy stosować dawne, obecnie uchylone przepisy prawa, w jakich zaś oprzeć się na przepisach nowych ${ }^{18}$. Z kolei J. Gwiazdomorski przyjmuje, że prawem intertemporalnym są rozstrzygnięcia prawodawcy co do tego, która z wchodzących w rachubę norm wyznacza daną sytuację prawną. W przeciwieństwie do Grzybowskiego Gwiazdomorski przyjmuje, że reguły te można odtwarzać jedynie z obowiązujących przepisów prawa ${ }^{19}$. Prawem intertemporalnym w ujęciu J. Mikołajewicza jest zbiór reguł, których celem jest określenie zakresu zastosowania norm prawnych w stosunku do sytuacji prawnych powstałych pod rządami prawa dawnego, ale wyłącznie od momentu wejścia w życie prawa nowego ${ }^{20}$. Jeszcze inne

15 Na przykład w tym kontekście S.L. Kaleda wspomina o nabieraniu przez akt prawny mocy prawnej (dzień dopełnienia czynności legislacyjnych) oraz nabieraniu przez akt mocy obowiązującej. Ten ostatni „punkt czasowy” utożsamia on z dniem wejścia w życie i możliwością stosowania aktu prawnego, por. tegoż, Przejęcie prawa wspólnotowego przez nowe państwo członkowskie. Zagadnienia przejściowe oraz międzyczasowe, Warszawa 2003, s. 115-116. W sprawie odniesienia się do zakresu czasowego obowiązywania przepisów por. np. P. Radziewicz, Umarzanie postępowania..., s. 27.

16 Por. J. Mikołajewicz, Prawo intertemporalne. Zagadnienia teoretycznoprawne, Poznań 2000, s. 34 i nn.

17 Zob. M. Sośniak, Konflikty w czasie norm cywilnoprawnych, Kraków 1962, Zeszyty Naukowe Uniwersytetu Jagiellońskiego, t. 48, s. 51.

18 Zob. System prawa cywilnego, t. 1. Część ogólna, red. S. Grzybowski, Wrocław 1985, s. 141.

19 Zob. J. Gwiazdomorski, Międzyczasowe prawo prywatne, Nowe Prawo 1965, nr 6, s. 614 .

20 Zdaniem J. Mikołajewicza przedmiotem tego, co można określić mianem „prawo intertemporalne”, jest udzielenie odpowiedzi na pytanie, która norma czy zespół norm prawnych wyznacza sytuację prawną z elementem dawnym (Prawo..., s. 60). W tej perspektywie reguły intertemporalne zawierają zarówno przepisy modyfikujące określone normy prawne, przepisy ujednoznaczniające, a nawet określone elementy przepisów ujednoznaczniających 
stanowisko prezentuje Z. Radwański ${ }^{21}$. W ocenie tego autora rozstrzygnięcie problemu intertemporalnego polega na doprecyzowaniu treści norm prawnych, wyznaczających sytuacje prawne z elementem dawnym po wejściu w życie norm nowych. W tym sensie jest mowa raczej o pewnej problematyce prawnej, a nie o podzbiorze zbioru prawa. Warta odnotowania jest również wypowiedź M. Kamińskiego, zgodnie z którą prawo intertemporalne obejmuje przepisy zawierające normy (reguły intertemporalne) służące rozgraniczeniu zakresów czasowych zastosowania reżimów dawnego i nowego prawa oraz określeniu wpływu nowej regulacji prawnej na stany faktyczne i stosunki prawne powstałe pod rządami regulacji dotąd obowiązującej ${ }^{22}$.

Nie rozstrzygając polemiki nad rozumieniem natury i zakresu problematyki międzyczasowej, w dalszej części opracowania punktem odniesienia będzie szeroko rozumiana "sytuacja intertemporalna”, mająca miejsce, gdy mimo zmiany prawa określone dotychczas sytuacje prawne trwają albo wywołują prawnie istotne skutki. Stwarza ona konieczność podjęcia rozstrzygnięcia intertemporalnego, określającego zakres działania prawa. Zdaniem Mikołajewicza treść rozstrzygnięć intertemporalnych można charakteryzować przez odwołanie się do trzech zasad: zasady bezpośredniego działania prawa, zasady dalszego działania prawa, zasady wyboru pra$w^{23}$. W. Jakimowicz podnosi dodatkowo, że ustawodawca może również skorzystać z zasady tempus regit actum, "zgodnie z którą zdarzenie prawne należy oceniać według stanu prawnego obowiązującego w dacie jego zaistnienia", oraz zasady wstecznego działania prawa, "gdzie nowe normy stosuje się do skutków prawnych «zamkniętych» pod rządami dawnego prawa" ${ }^{24}$. Jak wskazuje Jakimowicz, pierwsza z przywołanych przez niego zasad „wymaga szczególnej uwagi z perspektywy problematyki

określone normy prawne, metanormy, dyrektywy interpretacyjne, jak i przepisy zasadniczo wysławiające normy kompetencyjne, por. J. Mikołajewicz, Prawo..., s. 70, 73, 83.

21 Zob. Z. Radwański, Zarys części ogólnej prawa cywilnego, Warszawa 1981, s. 50.

22 Por. M. Kamiński, Prawo administracyjne..., s. 16-17. Pogląd ten przywołuje również W. Jakimowicz w opracowaniu Kilka uwag na temat metody regulacji intertemporalnej w kontekście sytuacji prawnej jednostki, w: Administracja publiczna pod rządami prawa. Księga pamiatkowa z okazji 70-lecia urodzin prof. zw. dra hab. Adama Błasia, red. J. Korczak, Wrocław 2016 [online], https://repozytorium.uni.wroc.pl/dlibra/publication/82612/edition/79094/content [dostęp: 25.01.2020 r.], s. 155.

23 Por. J. Mikołajewicz, Prawo..., s. 61-62.

24 Por. W. Jakimowicz, Kilka uwag..., s. 156. 
sytuacji prawnej jednostki, gdyż jest wiązana z zasadą ochrony praw dobrze (niewadliwie) nabytych, z której wynika zakaz arbitralnego znoszenia lub ograniczania praw podmiotowych publicznych i prywatnych przysługujących jednostce" 25 . Z kolei - jak podkreśla Trybunał Konstytucyjny z zasady państwa prawnego wynika zakaz retroaktywności prawa ${ }^{26}$.

Aby uniknąć zarzutu redukcjonizmu poznawczego ${ }^{27}$, w niniejszym opracowaniu pojęcia: problematyki, regulacji oraz rozstrzygnięć intertemporalnych będą używane w szerszym rozumieniu, uwzględniającym obszary objęte regulacjami stricte retroaktywnymi ${ }^{28}$.

Przyjęcie tej optyki jest obliczone na uchwycenie w polu analizy pełnego obszaru praw i interesów osób, które mogą być dotknięte, a nawet naruszone zmianą prawa. Ma to szczególne znaczenie na gruncie tak ingerencyjnej dziedziny, jaką są podatki. Poczucie krzywdy, w tym związane z naruszeniem godności adresatów norm prawnych, towarzyszy bowiem nie tylko ewidentnemu łamaniu ustawy zasadniczej, ale również przyjmowaniu rozwiązań legislacyjnych stanowionych na granicy ich konstytucyjności ${ }^{29}$.

\section{Sygnalizacja relewantnych pryncypiów katolickiej myśli społecznej}

Brak modyfikacji prawa z oczywistych względów nie jest możliwy, jednak każda zmiana stanu prawnego naraża podatników na dylematy związane ze stosowaniem właściwych przepisów oraz stawia przed prawodawcą wyzwania łączące się z respektowaniem przysługujących

25 Tamże, s. 156.

$26, \ldots[\ldots]$ czyli stosowania nowych norm prawnych do stanu faktycznego tzw. «zamkniętego», tj. w pełni ukształtowanego pod rządami przepisów wcześniej obowiązujących", tamże, s. 156-157 i przywołane tam orzecznictwo Trybunału Konstytucyjnego.

27 Por. E. Łętowska, w: Prawo intertemporalne w orzecznictwie..., s. 28.

${ }^{28} \mathrm{~W}$ tym znaczeniu M. Kłoda posługuje się pojęciem konfliktu międzyczasowego jako „możliwej konkurencji ustawy nowej i ustawy dawnej, z których każda jest powiązana z danym przypadkiem", tegoż, Prawo międzyczasowe..., s. 15.

29 Wśród szczególnie relewantnych podatkowo regulacji rangi konstytucyjnej, służących często jako wzorzec kontroli konstytucyjności prawa podatkowego, należy wymienić chociażby: art. 2, art. 84, art. 168, art. 217 Konstytucji Rzeczypospolitej Polskiej z dnia 2 kwietnia 1997 r., Dz. U z 1997 r. Nr 78, poz. 483 z późn. zm. (dalej: Konstytucja RP). 
obywatelom praw. Trudności te potęgują się, gdy skutki regulacji prawnych dotyczą bezpośrednio interesów majątkowych jednostek. Taka sytuacja ma miejsce w przypadku prawa podatkowego. Dzieje się tak, ponieważ dziedzina ta dotyczy bezpośredniego wkładu społeczeństwa w tzw. dobro wspólne, które, zgodnie z Katechizmem Kościoła Katolickiego, obejmuje trzy elementy:

1) poszanowanie osoby jako takiej (w tym wolności sumienia, ochrony życia prywatnego oraz sprawiedliwej wolności);

2) dobrobyt społeczny i rozwój społeczności (wraz z zapewnieniem wymogów niezbędnych do prowadzenia życia prawdziwie ludzkiego);

3) pokój i bezpieczeństwo ${ }^{30}$.

Zasada dobra wspólnego prowadzi poza obszar własnego ego, otwierając jednostkę na wspólnotę i jej potrzeby. Jest ona zakorzeniona we właściwym podejściu do człowieka i jego przyrodzonej godności jako stworzenia Bożego. Skutkiem zerwania przez ustawodawcę z zakotwiczeniem ogólnych wskazań dotyczących zmian systemu podatkowego w ludzkiej podmiotowości jest oscylacja w kierunku ukrytej lub jawnej formy totalitaryzmu ekonomicznego. W tym znaczeniu zaniechanie troski o etyczne umocowanie prawa podatkowego może naruszyć godność podatników, skutkując traktowaniem ich jako „bezwolnej masy”, która może lub winna być pozbawiona rozumienia reguł rządzących wspólnymi finansami, a tym samym potencjalnie zostać poddana wyzyskowi i wykorzystana ${ }^{31}$. Antidotum na tego rodzaju niebezpieczeństwa stanowi przestrzeganie reguł stanowienia prawa $\mathrm{z}$ uwzględnieniem zasad: personalizmu, dobra wspólnego, solidarności, sprawiedliwości i pomocniczości, miłości społecznej, obecnych w nauce społecznej Kościoła katolickiego ${ }^{32}$. Zasady te,

30 Por. Katechizm Kościoła Katolickiego, wyd. 2, Poznań 2002, 1907-1909 (dalej: KKK).

31 Por. A. Dylus, Gospodarka, moralność, chrześcijaństwo, Warszawa 1994, s. 131.

32 W podstawowym i szerokim ujęciu dobro wspólne to suma tych warunków życia społecznego, które pozwalają bądź to grupom, bądź poszczególnym jego członkom pełniej i szybciej osiągnąc ich własną doskonałość. W myśl pryncypiów zasady pomocniczości nie wolno jednostkom wydzierać i na społeczeństwo przenosić tego, co mogą one wykonać z własnej inicjatywy i własnymi siłami, przy czym dotyczy to odpowiednio mniejszych i niższych społeczności. Jednym z aspektów solidarności jest mocna i trwała wola angażowania się na rzecz dobra wspólnego, czyli dobra wszystkich i każdego. W najbardziej klasycznej definicji sprawiedliwości akcentuje się stałą i trwałą wolę oddania każdemu tego, co mu się należy, co przekłada się na postawę określoną przez wolę uznania drugiego jako 
jako całość, stanowią wyraz prawdy o społeczeństwie, a mając znaczenie głęboko moralne, odsyłają do ostatecznych fundamentów porządkujących życie społeczne. Historycznie istniejące społeczeństwo rodzi się bowiem ze splatania ze sobą wolności wszystkich osób, które w nim wzajemnie na siebie oddziałują przez dokonywane przez siebie wybory ${ }^{33}$.

Na gruncie polskiego systemu prawnego pewna część reguł realizowanych $w$ ramach tych zasad objęta jest prawną definicją demokratycznego państwa prawa. Z racji jej umieszczenia w art. 2 Konstytucji Rzeczypospolitej stanowi ona ogólny wzorzec kontroli przepisów ustawowych, w tym dotyczących zmian podatkowych ${ }^{34}$.

\section{Problemy międzyczasowe w świetle refleksji katolickiej myśli społecznej}

\section{Wybrane zagadnienia międzyczasowe}

Modyfikacje przepisów podatkowych często inspirowane są pojawiającą się koniecznością fiskalną. Dobrze jest, jeżeli ustawodawca pamięta o przeprowadzaniu ich $\mathrm{w}$ ramach oddzielnych regulacji prawnych, powalających ująć systemowo planowane zmiany. Pewną kontrolę tych zmian zapewnia obowiązek przeprowadzenia pełnego procesu legislacyjnego ${ }^{35}$.

Powszechnie znaną granicą aktywności ustawodawczej jest zakaz tworzenia prawa działającego wstecz. Pomijając dyskusje prowadzone

osoby. Tym samym tak rozumiana sprawiedliwość powraca do fundamentów personalistycznego traktowania wszystkich osób, bez ich uprzedmiotowienia i koniunkturalności. Z kolei miłość (w tym społeczna) zakłada sprawiedliwość, lecz ją przekracza, ta ostatnia bowiem musi znaleźć swoje dopełnienie, gdyż tylko miłość jest zdolna przywracać człowieka samemu człowiekowi. Szerzej na temat poszczególnych zasad katolickiej nauki społecznej zob. Papieska Rada Iustitia et Pax, Kompendium Nauki Społecznej..., nr 161-208. Por. też np. T. Borutka, J. Mazur, A. Zwoliński, Katolicka nauka społeczna, Częstochowa 1999, s. 51 i nn.

33 Papieska Rada Iustitia et Pax, Kompendium..., nr 162-163.

34 Szerzej zob. T. Bojkowski, Wolności oraz prawa konstytucyjne podatnika, Ruch Prawniczy, Ekonomiczny i Socjologiczny 2004, t. 66, z. 3, s. 116.

35 Por. art. 123 Konstytucji RP oraz art. 32 i nast. uchwały Sejmu Rzeczypospolitej Polskiej z dnia 30 lipca 1992 r. Regulamin Sejmu Rzeczypospolitej Polskiej, tekst jednolity: M.P. z 2020 r. poz. 327 z późn. zm. 
$\mathrm{w}$ doktrynie $\mathrm{w}$ przedmiocie interpretacji paremii lex retro non agit ${ }^{36}$, ostatecznie okazuje się, że każde powiązanie normy prawnej z przeszłością $\mathrm{w}$ zakresie stosowania wymaga usprawiedliwienia przynajmniej z punktu widzenia trzech zasad: trójpodziału władzy, zaufania obywateli do państwa oraz zasady ochrony wolności i własności ${ }^{37}$. Na szczególną uwagę zasługuje fakt, że zdaniem Trybunału Konstytucyjnego zakaz retroaktywności dotyczy jedynie regulacji, które mogą prowadzić do pogorszenia sytuacji dotkniętych nim podmiotów ${ }^{38}$. Co oczywiste, podane tu kryterium ma charakter par excellence wartościujący. Ponadto w orzecznictwie wyjątkowo dopuszcza się stosowanie prawa wstecz w sytuacji przeważania innych wartości konstytucyjnych ${ }^{39}$.

Innym ograniczeniem prawodawcy podatkowego jest obowiązek zachowania odpowiedniej vacatio legis. Ma on w szczególności na celu umożliwienie adresatom aktu normatywnego zapoznania się z jego treścią. W ocenie Sądu Najwyższego odpowiedni charakter vacatio legis winien być łączony z możliwością stworzenia adresatom norm prawnych realnej szansy przygotowania się do zmian $\mathrm{w}$ ich dotychczasowej sytuacji prawnej ${ }^{40}$. „Na stabilności i rozwojowym charakterze praw i obowiązków obywateli wspiera się [...] zaufanie obywateli do państwa i jego społeczna siła" ${ }^{41}$. Oznacza to, że zasada umacniania oraz rozszerzania praw i wolności konstytucyjnych wyznacza granicę dopuszczalnej ingerencji władzy publicznej w sferę podmiotowych praw jednostki. Zmiana prawa podatkowego bez okresu dostosowawczego nie licuje z podmiotowym traktowaniem adresatów tych norm. Ostatecznym celem prawa nie jest zaskakiwanie nieprzygotowanych podatników, ale spowodowanie ich uzasadnionego udziału w tworzeniu dobra wspólnego. Czynienie z legislacji pułapki nie ma żadnego związku z respektowaniem godności osobowej jej adresatów i jest pogwałceniem zasady podmiotowości, a nawet równości obywateli wobec prawa w stosunku do kręgu podatników, którzy wiedzieli

36 Por np. J. Mikołajewicz, Prawo..., s. 67 lub L. Morawski, Wstęp do prawoznawstwa, Toruń 2002, s. 142. Por. także T. Pietrzykowski, Wsteczne działanie prawa..., s. 119.

37 Por. W. Wróbel, Zmiana normatywna i zasady intertemporalne w prawie karnym, Kraków 2003, s. 335.

38 Por. orzeczenie TK z dnia 29 stycznia 1992 r., K 15/91, OTK ZU 1992, poz. 8.

39 Por. T. Pietrzykowski, Wsteczne dziatanie prawa..., s. 249.

40 Por. wyrok SN z dnia 13 marca 1997 r., I PKN 55/97, OSNAPiUS 1997, nr 13, poz. 235.

${ }^{41}$ Orzeczenie TK z dnia 30 listopada 1988 r., K 1/88, OTK 1988, poz. 6. 
wcześniej o projektowanych zmianach. Zaskakiwanie nagłymi zmianami prawa podatkowego zwykle odbija się na społecznym podejściu do jego respektowania. Stawianie podatników w trudnej sytuacji - przez niezapowiedzianą zmianę regulacji dotyczących ich żywotnych interesów - niszczy „wartość dodaną”, obecną w każdej zdrowej relacji demokratycznie wybranej władzy wobec obywateli. Na dłuższą metę trudno przecenić zaangażowanie podatników w dbałość o dobro wspólne. Jedynie poczucie wzajemnego szacunku państwa i osób podlegających jego prawom może stanowić fundament zrozumienia wzajemnych potrzeb i obowiązków. Stąd w literaturze przedmiotu artykułuje się niekiedy wprost katalog uzasadnionych reguł tworzenia prawa podatkowego ${ }^{42}$.

Nastawienie do kwestii podatkowej jest z reguły funkcją ogólnej relacji między obywatelami a władzą państwową. Zatem lekceważenie w tym obszarze zasad niedziałania prawa wstecz czy odpowiedniej vacatio legis podważa wiarę obywatela w rzetelność państwa, uderzając tym samym w gwarantowane przez nie prawo własności. Racja dobra wspólnego wydaje się bowiem odległa, gdy podatki kojarzą się bardziej z nieuprawnionym wywłaszczeniem niż solidarnym obowiązkiem wobec współobywateli. Zrozumienie solidarnościowego charakteru danin publicznych może odbywać się jedynie w atmosferze poszanowania zarówno przyrodzonych praw należnych osobie ludzkiej, jak i pochodnych wobec nich obowiązków wobec związku publicznoprawnego.

Brak poczucia bezpieczeństwa gospodarczego hamuje inicjatywę inwestycyjną, zatrzymuje ludzi w „szarej strefie” i rujnuje uczciwą konkurencję. Podmioty zagrożone wymiarem podatku, którego nie sposób precyzyjnie przewidzieć, mogą poczuć się zwolnione z obowiązku przestrzegania prawa podatkowego, skoro jego znajomość nie jest obiektywnie możliwa. Dlatego stanowienie niespójnego i „nieczytelnego" społecznie prawa stoi w sprzeczności z podmiotowym traktowaniem jego adresatów. Trudny dylemat pomiędzy określoną szczegółowością rozwiązań prawnych a klarownością ustawy musi być rozwiązywany w duchu zrozumienia społecznej percepcji stanowionych regulacji. Szczególnie szkodliwe są wypadki

42 Obejmuje on m.in. zasadę: nakładania podatków jedynie w drodze ustawy parlamentarnej, ochrony źródła podatku, respektowania praw i prawidłowości ekonomicznych jako granic regulacji prawnopodatkowych, przewidywania długookresowych i krótkookresowych skutków regulacji podatkowych czy ograniczenia wpływu deprecjacji pieniądza na trwałość regulacji podatkowo-prawnych, por. B. Brzeziński, Wstęp do nauki prawa podatkowego, Toruń 2001, s. 118-120. 
niejasności w relacjach przejściowych. Ich niespójność i brak jednoznacznych rozstrzygnięć co do zakresu stosowania prawa rzutuje bowiem niejednokrotnie na ukształtowanie sytuacji podatnika w dłuższej perspektywie.

Również niepokojące mogą być niezapowiedziane wcześniej zmiany w obszarze reguł prowadzenia dokumentacji podatkowej. Przerost regulacji, ich niestabilność oraz zbyt daleko idąca drobiazgowość, powodująca rozrost ustaw do rozmiarów uniemożliwiających zapoznanie się z nimi przez przeciętnego obywatela, może stać się przyczynkiem do podjęcia działań idących contra legem czy praeter legem. Zmuszanie podatników do zapoznawania się z napisanymi fachowym językiem aktami prawnymi o niespotykanej wcześniej objętości nie może odnieść pozytywnego skutku. Efektem tego typu aktywności prawodawczej może być, obok uchylania się od opodatkowania, istotne zaburzenie uczciwej konkurencji.

W przypadku regulacji bezpośrednio dotykających interesów gospodarczych niezwykle istotna jest sama trwałość unormowań. Nie sposób racjonalnie planować działań biznesowych w obliczu szybko zmieniających się warunków prawnych. Warunki takie gaszą inicjatywę gospodarczą potencjalnych przedsiębiorców, zachęcają do bierności oraz pogłębiają poczucie niesprawiedliwości. Permanentne zmiany normatywne aktów prawnych stwarzają sytuacje, w których prawidłowe odczytanie istotnego dla danego rozstrzygnięcia przepisu może być poważnie utrudnione nie tylko przeciętnemu obywatelowi, ale i osobie legitymującej się wykształceniem prawniczym ${ }^{43}$. Stąd nieprzemyślane i częste zmiany prawa podatkowego mocno godzą $\mathrm{w}$ fundament poczucia podmiotowości tych, których to prawo dotyka.

Po pewnym okresie obowiązywania niesprawiedliwego prawa trudniej przekonać kogokolwiek do postaw legalistycznych. Wzbudzona nieufność będzie miała poważne oddziaływanie społeczne, wpływając na kształtowanie się kultury prawnej i zachowań podatników. Wymaganie od podatnika rzetelnego wywiązywania się z obowiązku podatkowego jest uprawnione jedynie wobec rzeczywiście należnych świadczeń. Podatek, aby był sprawiedliwy i mógł być zapłacony w duchu solidarności, winien co najmniej wynikać z konstytucyjnie umocowanej i w pełni legalnej podstawy prawnej.

Niepewność co do zakresu stosowania norm prawnych sprzyja licznym rozbieżnościom orzeczniczym. Rzeczowe może okazać się wówczas

${ }^{43}$ Por. wyrok NSA z dnia 7 czerwca 1996 r., SA/Gd 1830/95, ONSA 1997, nr 2, poz. 92. 
pytanie: czy wymogi zgłaszane wobec sędziów Sądu Najwyższego przy wykładni ustaw finansowych można stawiać każdemu adresatowi normy prawnopodatkowej? Czy takie prawo koresponduje z personalistyczną wizją człowieka? Ustabilizowana praktyka orzecznicza jest fundamentem pewności i stabilności prawa, wyrażających się w większej jego przewidywalności ${ }^{44}$. Ukształtowana na tych wartościach kultura prawa podatkowego może stać się nośnikiem bardziej ogólnej aksjologii społecznej, przejawiającej się $\mathrm{w}$ respektowaniu chociażby poszanowania ludzkiej godności, zasady sprawiedliwości społecznej czy powiązanej z nią zasady równości. Treścią zasady ochrony praw nabytych jest zakaz arbitralnego ograniczania oraz pozbawiania praw podmiotowych i ich ekspektatyw ukształtowanych przez obowiązujące ustawy ${ }^{45}$. Mowa tu wprost o działaniu arbitralnym, co nie wyklucza dopuszczalności ograniczenia, a nawet pozbawienia obywatela prawa podmiotowego, jeżeli wymaga tego odpowiednio ważny interes społeczny ${ }^{46}$. Zdaniem Rzecznika Praw Obywatelskich zasada zaufania może być naruszona tylko w przypadku eliminacji z systemu arbitralnie ustanowionych preferencji grupowych, a co do zasady realizacja celów gospodarczych w sytuacji trudności gospodarczych nie może usprawiedliwiać nieprzestrzegania konstytucyjnych reguł tworzenia prawa oraz zasady zaufania obywatela do państwa i związanej $\mathrm{z}$ nią zasady ochrony praw nabytych ${ }^{47}$.

Zatem ocena dopuszczalności ograniczeń praw przysługujących podmiotom wymaga rozważania m.in. tego, czy wprowadzone ograniczenia znajdują podstawę w innych normach, zasadach lub wartościach konstytucyjnych oraz czy zachodzi możliwość realizacji danej normy, zasady lub wartości konstytucyjnej bez naruszenia praw nabytych. Ponadto przedmiotem analizy powinno być to, czy wartościom konstytucyjnym, dla realizacji których prawodawca ogranicza prawa nabyte, można w konkretnej sytuacji przyznać pierwszeństwo przed wartościami znajdującymi się u podstaw zasady ochrony praw nabytych oraz to, czy prawodawca

44 Por. K. Osajda, Znaczenie zasad prawnych dla wykładni prawa (na przykładzie prawa cywilnego), w: Teoria i praktyka wykładni prawa, red. P. Winczorek, Warszawa 2005, s. 274.

45 Por. M. Wyrzykowski, Zasada demokratycznego państwa prawnego, w: Zasady podstawowe polskiej Konstytucji, red. W. Sokolewicz, Warszawa 1998, s. 85.

46 Por. orzeczenie TK z dnia 4 października 1989 r., K 3/88, OTK ZU 1989, poz. 2.

47 Por. uzasadnienie orzeczenia TK z dnia 11 lutego 1992 r., K 14/91, OTK ZU 1992, poz. 7. 
podjął niezbędne działania mające na celu zapewnienie jednostce warunków do przystosowania się do nowej regulacji ${ }^{48}$.

W ocenie Trybunału Konstytucyjnego, wyrażonej w uzasadnieniu orzeczenia z dnia 4 grudnia 1990 r., ustawodawca może ograniczyć prawa nabyte, jeżeli ich utrzymanie w zmienionej sytuacji gospodarczej spowodowałoby sytuację niesprawiedliwego uprzywilejowania kosztem pozostałej części społeczeństwa ${ }^{49}$. „W przypadku ograniczenia czy pozbawienia praw nabytych ustawodawca winien wyważyć interes publiczny i prywatny, konstruując przepis w taki sposób, aby ochrona interesu publicznego nie powodowała nadmiernego uszczerbku dla interesu prywatnego" ${ }^{50}$. Jednocześnie wszelkie próby traktowania podatników jako jednorodnej grupy i rozliczania zbiorczo ich strat i zysków nie miałyby podstaw w konstytucyjnej - zindywidualizowanej, a nie kolektywistycznej - koncepcji praw jednostki ${ }^{51}$.

W tym miejscu warto wskazać na relację zasady ochrony praw nabytych do omawianych już: zakazu lex retro non agit i obowiązkowego spoczywania ustawy. Co do pierwszego zagadnienia, nienaruszenie zakazu retroaktywności prawa nie oznacza równocześnie automatycznego poszanowania praw nabytych. Jeżeli chodzi o spoczywanie ustawy, to nakaz zachowania odpowiedniej vacatio legis odnosi się do wszelkich regulacji podatkowych, nie zaś tylko tych, które ograniczają lub znoszą prawa podmiotowe ${ }^{52}$.

Kolejną z kwestii bezpośrednio odnoszących się do stabilności sytuacji prawnej podatników jest poszanowanie interesów w toku. Rzeczywiste respektowanie przez państwo osobowej wizji człowieka musi skutkować szacunkiem poszczególnych ludzi i grup społecznych do podejmowanych przez człowieka aktywności i czynionych przez niego planów. Obowiązek rozsądnego, również w znaczeniu gospodarczym, planowania należy do porządku naturalnego, a brak należytej roztropności w tym przedmiocie stał się nawet elementem przypowieści Zbawiciela ${ }^{53}$.

48 Por. wyrok TK z dnia 17 listopada 2003 r., K 32/02, OTK ZU 2003, nr 9A, poz. 93.

49 Por. orzeczenie TK z dnia 4 grudnia 1990 r., K 12/90, OTK ZU 1990, poz. 7.

50 Wyrok TK z dnia 8 kwietnia 1998 r., K 10/97, OTK ZU 1998, nr 3, poz. 29.

51 Orzeczenie TK z dnia 24 maja 1994 r., K 1/94, OTK ZU 1994, poz. 10.

52 Por. wnioski płynące z uzasadnienia wyroku TK z dnia 1 lipca 2003 r., P 31/02, OTK ZU 2003, nr 6A, poz. 58.

53 Zob. Łk 14, 28-32 (Pismo Święte Starego i Nowego Testamentu, wyd. 3, Poznań-Warszawa 1980 , s. 1200). 
Przedstawiona w orzecznictwie definicja interesów w toku obejmuje spełnienie trzech warunków:

1) ustawodawca wyznaczył pewne ramy czasowe, w których jednostka może realizować określone przedsięwzięcie według z góry ustalonych reguł;

2) dane przedsięwzięcie ma charakter rozłożony w czasie;

3) podmiot faktycznie rozpoczął realizację danego przedsięwzięcia ${ }^{54}$.

Gwarancja realizacji tak określonych przedsięwzięć „wymaga, by sytuacja prawna osób dotkniętych nową regulacją była poddana takim przepisom przejściowym, by mogły mieć one czas na dokończenie przedsięwzięć podjętych na podstawie wcześniejszej regulacji, w przeświadczeniu, że będzie ona miała charakter stabilny" ${ }^{\prime \prime 5}$. Istotne jest zatem, aby podatnik mógł układać swoje sprawy z przekonaniem, że nie naraża się na prawne skutki, których nie mógł przewidzieć w momencie podejmowania decyzji. Ostatecznie jednak brakuje wiążącej wskazówki normatywnej, gdzie jest granica pomiędzy tzw. przechwyceniem "sytuacji w toku” przez nowe prawo a stosowaniem nowej ustawy poprzez określenie na nowo skutków prawnych faktów zaistniałych w przeszłości. W tym stanie rzeczy, przy braku jednoznacznych regulacji intertemporalnych, nie jest łatwo znaleźć uniwersalne rozwiązanie. Dlatego też dla ich wypracowania istotne znaczenie ma zarówno właściwa legislacja, odpowiednia kultura prawna prawodawcy i stosujących prawo, jak i funkcjonalne podejście sądów administracyjnych ${ }^{56}$.

\section{Perspektywa refleksji w obszarze społecznej myśli katolickiej}

Prezentowane tu reguły poszanowania praw jednostki wpisują się w akcentowaną w katolickiej myśli społecznej osobową koncepcję człowieka. Jest ona oparta na przyrodzonej i niezbywalnej godności oraz domaga się poszanowania zarówno ze strony współobywateli, jak i organów władzy publicznej. Właściwe rozumienie tej zasady leży u podstaw respektowania ludzkiej autonomii oraz szacunku dla podejmowanych przez człowieka wolnych wyborów, w tym w dziedzinie ekonomii. Takie podejście do podatnika domaga się przewidywalności działań władzy publicznej, co

\footnotetext{
54 Por. orzeczenie TK z dnia 25 kwietnia 2001 r., K 13/01, OTK ZU 2001, nr 4, poz. 81.

55 Orzeczenie TK z dnia 15 lipca 1996 r., K 5/96, OTK ZU 1996, nr 4, poz. 30.

56 Por. J. Małecki, Kwestie intertemporalne..., s. 153.
} 
powinno pozwolić na zrozumienie nakładanych na podatnika obowiązków oraz możliwości ich rzetelnej realizacji w rozsądnym czasie.

Każda forma ingerencji w prawo własności musi odbywać się $\mathrm{w}$ nakreślonych prawem granicach. Obok kryterium racjonalności wymagane jest zachowanie przez prawodawcę reguł przyzwoitej legislacji, traktującej godność obciążonych w sposób jej należny. Chodzi o ochronę przed arbitralnymi zmianami czy bezprawiem proceduralnym. Jest to konkretyzacja prawnego rozumienia zasady proporcjonalności w stosunku do działań legislacyjnych, które pociągają za sobą ograniczenie bezpieczeństwa prawnego jednostki ${ }^{57}$. „Wszelkie budzące wątpliwości regulacje prawne nieokreślające jasno, kto jest podmiotem uprawnionym - jednostka czy państwo - traktować należy jako sferę swobody jednostki", co oznacza akceptację na gruncie jurydycznym prawa publicznego reguły, że: to, co nie jest prawnie zakazane, jest prawnie dozwolone ${ }^{58}$. W tym rozumieniu interes publiczny jest w pewnym sensie pochodną interesów indywidualnych, a nie odwrotnie.

Ludzka praca przynosi korzyść zarówno wykonującemu ją, jak i wspólnocie, do której wykonujący należy. Dzieje się tak w ramach realizacji powołania człowieka jako wolnego podmiotu mogącego czynić dar z samego siebie. W tym sensie doczesny produkt ludzkiego wysiłku własność - znajduje swoje indywidualne i społeczne uzasadnienie. Zysk (dochód) jest wskaźnikiem dobrego funkcjonowania przedsiębiorstwa, przy czym nie jest to jedyny cel ludzkiej pracy. Zaangażowanie człowieka $\mathrm{w}$ dzieło zmiany oblicza świata ma również istotny wpływ na relacje międzyludzkie oraz życie wspólnoty ludzi, których losy są związane $\mathrm{z}$ podatnikiem. Zmiana prawa, w tym podatkowego, w sposób nielicujący z godnością jego adresatów świadczy o arogancji władzy, która gubi rację swojego przywództwa jako pochodnej woli obywateli.

Zasada solidarności może być odczytana również na płaszczyźnie współpracy państwo - podatnik. W swej istocie opiera się ona na założeniu służby wobec człowieka, w uznaniu jego podmiotowości i niezbywalnej godności ${ }^{59}$. Z drugiej strony ta sama solidarność nakazuje uczciwe płacenie

57 Por. wyrok TK z dnia 10 lipca 2000 r., SK 21/99, OTK ZU 2000, nr 5, poz. 144.

58 Por. W. Jakimowicz, Publiczne prawa podmiotowe, Kraków 2002, s. 83.

59 Por. Jan Paweł II, Encyklika Sollicitudo rei socialis (30.12.1987 r.), 38, tekst polski: serwis internetowy Opoka, https://opoka.org.pl/biblioteka/W/WP/jan_pawel_ii/encykliki/sollicitudo.html [dostęp: 20.06.2019 r.]. 
należnych podatków, cojest wyrazem odpowiedzialności za drugiego człowieka i dobro wspólne.

Zagmatwane regulacje nowych, zbyt pospiesznie wprowadzanych zmian przepisów nie pozwalają na spokojne dostosowanie się podatników do nowej rzeczywistości prawnej. Może to prowadzić do podziału podatników na lepiej i gorzej zorientowanych, zaburzając reguły zdrowej konkurencji i modelując rynek zależnie od obsługi prawnej, na którą stać podatnika. Tak zwane prawo dla prawników jest rozwiązaniem trudnym do zaakceptowania i świadczy o istotnej niemocy stanowiących go organów władzy, niemogących sprostać wymogom personalistycznego podejścia do możliwości poznawczych podatników.

Podobnie rzecz ma się z nieumiejętnym wprowadzeniem nowych rozwiązań podatkowych, prowadzącym do wygaszania inicjatywy gospodarczej obywateli. Negowanie lub ograniczanie prawa do inicjatywy gospodarczej w imię rzekomej równości faktycznie niweluje przedsiębiorczość, czyli twórczą podmiotowość obywatela. Zamiast niej rodzi się bierność, zależność i podporządkowanie wobec biurokratycznego aparatu, który stawia wszystkich w pozycji mniej lub bardziej totalnej zależności ${ }^{60}$.

Tradycyjna teologia moralna stawiała sprawiedliwemu opodatkowaniu trzy wymogi:

1) zarządzenie przez legalną zwierzchność;

2) ograniczenie do tego, co niezbędne dla dobra wspólnego;

3) sprawiedliwy podział ciężarów na jednostki ${ }^{61}$.

Zdaniem papieża Piusa XI podstawą sprawiedliwości społecznej jest to, by od każdego wymagać tego, co konieczne dla dobra wspólnego ${ }^{62}$.

60 Szerzej w sprawie krytyki błędów socjalizmu por. Jan Paweł II, Encyklika Centesimus annus, 13, 15, 25, tekst polski: serwis internetowy Opoka, https://opoka.org.pl/ biblioteka/W/WP/jan_pawel_ii/encykliki/centesimus_2.html [dostęp: 20.06.2019 r.].

61 Por. J. Wiemeyer, Podatki jako problem etyczno-społeczny, w: Katolicka nauka społeczna. Podstawowe zagadnienia z życia gospodarczego, red. J. Kupny, S. Fel, Katowice 2003, s. 187.

62 Por. Pius XI, Encyklika Divini Redemtoris (19.03.1937 r.), 51, tekst polski: serwis internetowy Opoka, https://opoka.org.pl/biblioteka/W/WP/pius_xi/encykliki/divini_redemptoris_19031937.html [dostęp: 20.06.2019 r.]. Realizację pojęcia tak rozumianego dobra wspólnego uzależnił papież Jan Paweł II od spełnienia takich warunków, jak: prawo do zaspokojenia potrzeb materialnych, gwarancja wolności w podstawowych zakresach i ochrona stosunków istotnych dla uczestnictwa w życiu społeczeństwa, por. Kościót wobec wspótczesnych problemów życia gospodarczego. Społeczne dokumenty episkopatów, red. S. Fel, J. Kupny, Lublin 2002, s. 51. 
Obliguje to do ustalenia podstawowego poziomu materialnego dobrobytu dostępnego dla wszystkich, a środki do tego konieczne winien dostarczyć system podatkowy oparty na możliwości płacenia daniny. Inaczej rzecz ujmując, sprawiedliwe opodatkowanie zapewnia:

- powszechność,

- równomierność, przejawiającą się w porównywalnym opodatkowaniu podobnych zjawisk gospodarczych,

- wystarczający poziom fiskalizacji dla dostarczenia dochodów budżetowych, z uwzględnieniem opcji dla ubogich,

- wyrównanie socjalne, polegające na solidarności bogatych z mniej zamożnymi ${ }^{63}$.

Zmiany w prawie podatkowym jako element systemu gospodarczego nie mogą niszczyć charyzmatu uczciwej współpracy obywateli czy rodzić postawę bierności wobec niepewnego jutra. Nie można doprowadzać do utraty ludzkiej energii na zapoznawanie się ze zbyt skomplikowanymi konstrukcjami nowych regulacji, zwłaszcza jeśli te ostatnie nie zawierają w sobie potencjału stabilności w dłuższej perspektywie. Nieprzemyślana ingerencja państwa $\mathrm{w}$ omawianym obszarze może prowadzić do zaprzeczenia gospodarczego aspektu ludzkiej wolności, będącej obok samoświadomości i zdolności poznania prawdy fundamentem naturalnej godności każdego człowieka. Interwencja gospodarcza państwa „winna być tak wykonywana, aby nie hamowała wolności działania osób prywatnych, lecz przeciwnie, aby ją zwiększała" ${ }^{64}$.

W duchu zasady pomocniczości państwo powinno uczciwie rozważyć rzeczywistą potrzebę zmiany, a zwłaszcza zwiększania skali obciążeń podatkowych. Zbieranie podatków na cele, których państwo nie powinno finansować, obniża bowiem morale fiskalne podatników, prowadząc zwykle dodatkowo do innych niekorzystnych skutków społecznych (np. przyzwyczajenia do korzystania z nieuzasadnionej pomocy publicznej, bierności, korupcji czy hamowania zdrowej konkurencji).

Ostatecznie dobro wspólne nie może być rozumiane inaczej niż stwarzanie warunków dla integralnego rozwoju człowieka, w tym podatnika. Ludzka przedsiębiorczość obejmuje prawo do prywatnej inicjatywy

63 Por. J. Wiemeyer, Podatki jako problem..., s. 190.

64 Jan XXIII, Encyklika Pacem in terris (11.04.1963 r.), 65, tekst polski: serwis internetowy Opoka, https://opoka.org.pl/biblioteka/W/WP/jan_xxiii/encykliki/pacem_in_terris_11041963.html [dostęp: 20.06.2019 r.]. 
gospodarczej, zasadę jej swobody związaną z prawem do posiadania i niezależności w zaspokajaniu potrzeb, pierwszeństwo pracy nad kapitałem, twórczą rolę pracy i wynalazków oraz tworzenie ekonomii przedsiębiorstwa w oparciu o czynnik ludzki ${ }^{65}$. W tym znaczeniu bazą dla działalności gospodarczej winien być zrównoważony rozwój społeczno-gospodarczy, mający u podstaw poszanowanie prawa pracy i własności prywatnej. Zarówno "szara strefa” w sferze gospodarczej, jak i nieuzasadnione wywłaszczenie prywatnej własności pod płaszczem danin publicznych nie mogą przyczynić się do rozszerzania bonum commune.

Warto nadmienić, że szczególną racją zmian podatkowych może być racjonalizacja systemu podatkowego. Niepłacenie należnych podatków jest wykroczeniem zarówno przeciwko zasadzie solidarności społecznej, jak i zasadzie sprawiedliwości ${ }^{66}$.

Zbieranie podatków i wydatki publiczne nabierają fundamentalnej wagi ekonomicznej dla każdej wspólnoty obywatelskiej i politycznej; celem, do którego winno się zdążać, jest system finansów publicznych, będący także narzędziem rozwoju i solidarności. Sprawiedliwy, skuteczny i wydajny system finansów publicznych daje dobre wyniki w dziedzinie ekonomii, ponieważ wspiera rozwój zatrudnienia, podtrzymuje działalność przedsiębiorczą oraz inicjatywy bezdochodowe, zwiększa też wiarygodność państwa jako gwaranta systemów ochrony ubezpieczeń społecznych, szczególnie nastawionych na ochronę najsłabszych. [...] W podziale zasobów finanse publiczne muszą podążać drogą solidarności, równości, dowartościowania talentów i muszą też ze szczególną uwagą wspierać rodziny, przeznaczając na ten cel odpowiednią ilość zasobów ${ }^{67}$.

Działając w warunkach źle pojętej wolności i nieograniczonej konkurencji, ludzie nabywają bowiem skłonności do przekraczania sprawiedliwości i miłosierdzia ${ }^{68}$. Odwołanie się do zasad katolickiej myśli społecznej powinno przypomnieć o podstawowych prawach, lecz także obowiązkach obywateli jako członkach wspólnoty narodowej i osobach wezwanych do współdziałania w Bożym planie zbawienia.

65 Tamże, 42.

66 Por. KKK, 1880 i 1916.

67 Papieska Rada Iustitia et Pax, Kompendium Nauki Społecznej..., nr 355.

68 Por. E. Kozerska, Państwo i społeczeństwo w poglądach Piusa XI, Wrocław 2005, s. 133. 


\section{Zakończenie}

Wypracowane w nauce prawa podatkowego oraz orzecznictwie zasady wspierające podmiotową wizję człowieka zasługują na uznanie. Właściwa antropologia, oparta na respektowaniu ludzkiej godności, powinna stanowić zawsze naczelną dyrektywę stanowienia i stosowania norm prawnych. W przeciwnym razie może pojawić się niebezpieczeństwo pokusy podporządkowywania rozwiązań normatywnych, zwłaszcza o charakterze bezwzględnie obowiązującym, doraźnym celom politycznym czy koniunkturalnym.

Etyczne podejście do systemu podatkowego zakłada zatem zagwarantowanie właściwie rozumianej wolności i związanych z nią swobód: konkurencji, wyboru życiowego zajęcia, prywatnej przedsiębiorczości, jak również przestrzegania poszanowania własności prywatnej ${ }^{69}$. Jednocześnie dla etycznej oceny systemu podatkowego istotna jest kwestia sprawiedliwości, i to zarówno legalnej (rządzącej stosunkiem podatnika wobec fiskusa), jak i dystrybutywnej (przejawiającej się w odpowiednim rozłożeniu ciężarów podatkowych). Nałożenie podatków, gdy są uzasadnione co do wysokości i sprawiedliwie rozłożone, pełni też bowiem funkcję wyrównywania bogactwa nie tylko na korzyść tych, którzy potrzebują pomocy, ale także jako ewentualne wsparcie zdrowych inwestycji i wzrostu rzeczywistej gospodarki. Zasygnalizowane optyki danin publicznych zbiegają się we właściwym rozumieniu solidarnej odpowiedzialności za dobro wspólne. Jest to tym bardziej istotne, że "podatki są wyrazem solidarności ekonomicznej nie tylko w ramach obecnego pokolenia, lecz też pokoleń starszych, czy dopiero wzrastających"70.

Dzięki uznaniu i realizacji wewnętrznego związku istniejącego między rozumowaniem ekonomicznym i etycznym powstaje dobro, które może przynieść korzyść całej ludzkości ${ }^{71}$. Niedostatek moralny pogłębia bowiem niedoskonałości mechanizmów rynku ${ }^{72}$. Obecność argumentów

${ }_{69}$ Por. D. Dańkowski, Podatki i moralność, Znak 1998, nr 2, s. 73-75.

70 Por. A. Zwoliński, Katolik i pieniądze, Częstochowa 2007, s. 182.

71 Por. Benedykt XVI, Encyklika Caritas in veritate (29.06.2009 r.), 36, tekst polski: serwis internetowy Opoka, https://opoka.org.pl/biblioteka/W/WP/benedykt_xvi/encykliki/ca ritas_in_veritate_29062009.html [dostęp: 20.06.2019 r.].

72 Por. Franciszek, Encyklika Laudato si (24.05.2015 r.), 189, tekst polski: serwis internetowy Opoka, https://opoka.org.pl/biblioteka/W/WP/franciszek_i/encykliki/laudato_ si_24052015.html [dostęp: 20.06.2019 r.]. 
etycznych $\mathrm{w}$ obszarze stanowienia norm podatkowych, zwłaszcza międzyczasowych, pozwala na bardziej stabilny rozwój gospodarczy, płynący z poczucia bezpieczeństwa ekonomicznego i wzajemnego zaufania.

Umiejętność zdrowego wyważenia interesów obywateli i dobra wspólnego, przy uwzględnieniu pochodnej roli państwa wobec pozycji i praw jednostki, wydaje się być kluczem do właściwej polityki podatkowej, również w obszarze prawa intertemporalnego. W państwach demokratycznych to stosunek do płacenia podatków niejednokrotnie ujawnia rzeczywiste odniesienie jednostki do społeczeństwa, a brak rzetelnej i stałej refleksji w tym obszarze może prowadzić do postaw aspołecznych. Racje przedstawiane w katolickiej nauce społecznej mogą pomóc w wypracowaniu standardów polityki zmian regulacji podatkowych, stanowiąc punkt odniesienia dla podejmowanych działań legislacyjnych. Ponadto mogą one dostarczyć argumentów w procesie edukacji społecznej dotyczącej podatków w kontekście respektowania zasad: podmiotowości, dobra wspólnego, solidarności, sprawiedliwości czy pomocniczości.

\section{Bibliografia}

\section{Źródła}

\section{Akty prawne}

Konstytucja Rzeczypospolitej Polskiej z dnia 2 kwietnia 1997 r., Dz. U z 1997 r.

Nr 78, poz. 483 z późn. zm.

Uchwała Sejmu Rzeczypospolitej Polskiej z dnia 30 lipca 1992 r. Regulamin Sejmu

Rzeczypospolitej Polskiej, tekst jednolity: M.P. z 2020 r. poz. 327 z późn. zm.

\section{Orzecznictwo}

Orzeczenie TK z dnia 30 listopada 1988 r., K 1/88, OTK ZU 1988, poz. 6.

Orzeczenie TK z dnia 4 października 1989 r., K 3/88, OTK ZU 1989, poz. 2.

Orzeczenie TK z dnia 4 grudnia 1990 r., K 12/90, OTK ZU 1990, poz. 7.

Orzeczenie TK z dnia 8 stycznia 1991 r., P 1/90, OTK ZU 1991, poz. 6.

Orzeczenie TK z dnia 29 stycznia 1992 r., K 15/91, OTK ZU 1992, poz. 8.

Orzeczenie TK z dnia 11 lutego 1992 r., K 14/91, OTK ZU 1992, poz. 7.

Orzeczenie TK z dnia 11 kwietnia 1994 r., K 10/93, OTK ZU 1994, poz. 7.

Orzeczenie TK z dnia 24 maja 1994 r., K 1/94, OTK ZU 1994, poz. 10.

Orzeczenie TK z dnia 15 lipca 1996 r., K 5/96, OTK ZU 1996, nr 4, poz. 30. 
Orzeczenie TK z dnia 25 kwietnia 2001 r., K 13/01, OTK ZU 2001, nr 4, poz. 81.

Wyrok NSA z dnia 7 czerwca 1996 r., SA/Gd 1830/95, ONSA 1997, nr 2, poz. 92. Wyrok SN z dnia 13 marca 1997 r., I PKN 55/97, OSNAPiUS 1997, nr 13, poz. 235. Wyrok TK z dnia 8 kwietnia 1998 r., K 10/97, OTK ZU 1998, nr 3, poz. 29.

Wyrok TK z dnia 10 lipca 2000 r., SK 21/99, OTK ZU 2000, nr 5, poz. 144.

Wyrok TK z dnia 1 lipca 2003 r., P 31/02, OTK ZU 2003, nr 6A, poz. 58.

Wyrok TK z dnia 17 listopada 2003 r., K 32/02, OTK ZU 2003, nr 9A, poz. 93.

\section{Źródła prawa i dokumenty Kościoła}

Pius XI, Encyklika Divini Redemtoris (19.03.1937 r.), tekst polski: serwis internetowy Opoka, https://opoka.org.pl/biblioteka/W/WP/pius_xi/encykliki/divini_ redemptoris_19031937.html [dostęp: 20.06.2019 r.].

Jan XXIII, Encyklika Pacem in terris (11.04.1963 r.), tekst polski: serwis internetowy Opoka, https://opoka.org.pl/biblioteka/W/WP/jan_xxiii/encykliki/pacem_in_terris_11041963.html [dostęp: 20.06.2019 r.].

Jan Paweł II, Encyklika Sollicitudo rei socialis (30.12.1987 r.), tekst polski: serwis internetowy Opoka, https://opoka.org.pl/biblioteka/W/WP/jan_pawel_ii/ency kliki/sollicitudo.html [dostęp: 20.06.2019].

Jan Paweł II, Encyklika Centesimus annus (1.05.1991 r.), tekst polski: serwis internetowy Opoka, https://opoka.org.pl/biblioteka/W/WP/jan_pawel_ii/encykliki/centesimus_2.html [dostęp: 20.06.2019 r.].

Benedykt XVI, Encyklika Caritas in veritate (29.06.2009 r.), tekst polski: serwis internetowy Opoka, https://opoka.org.pl/biblioteka/W/WP/benedykt_xvi/ encykliki/caritas_in_veritate_29062009.html [dostęp: 20.06.2019 r.].

Franciszek, Encyklika Laudato si (24.05.2015 r.), tekst polski: serwis internetowy Opoka, https://opoka.org.pl/biblioteka/W/WP/franciszek_i/encykliki/laudato_si_24052015.html [dostęp: 20.06.2019 r.].

Katechizm Kościoła Katolickiego, wyd. 2, Poznań 2002.

Papieska Rada Iustitia et Pax, Kompendium Nauki Społecznej Kościoła, Kielce 2005.

Pismo Święte Starego i Nowego Testamentu, wyd. 3, Poznań-Warszawa 1980.

\section{Literatura}

Aarnio A., O obowiązywaniu, skuteczności i akceptowalności norm prawnych, Acta Universitatis Lodziensis. Folia Iuridica 1987, t. 32.

Ballard A.F., Retroactive Federal Taxation, Harvard Law Review 1935, nr 48.

Bąbiak-Kowalska D., w: Prawo intertemporalne w orzecznictwie Trybunału Konstytucyjnego i Sądu Najwyższego, red. E. Łętowska, K. Osajda, Warszawa 2008.

Bojkowski T., Wolności oraz prawa konstytucyjne podatnika, Ruch Prawniczy, Ekonomiczny i Socjologiczny 2004, t. 66, z. 3.

Bonneau T., La Cour de Cassation et l'application de la loi dans le temps, Paris 1990. 
Borutka T., Mazur J., Zwoliński A., Katolicka nauka społeczna, Częstochowa 1999.

Brolik J., Wybrane zagadnienia przestrzegania prawa w procesie samoobliczenia podatku, w: Ius et lex. Księga Jubileuszowa Profesora Andrzeja Kabata, red. S. Pikulski i in., Olsztyn 2004.

Brzeziński B., Wstęp do nauki prawa podatkowego, Torun 2001.

Dańkowski D., Podatki i moralność, Znak 1998, nr 2.

Duniewska Z., Instytucja vacatio legis w prawie administracyjnym, Studia Prawno-Ekonomiczne 1997, t. 56.

Dylus A., Gospodarka, moralność, chrześcijaństwo, Warszawa 1994.

Etel L., Wejście w życie uchwat podatkowych - wybrane problemy, w: W kręgu prawa podatkowego i finansów publicznych. Księga dedykowana Profesorowi C. Kosikowskiemu w 40-lecie pracy naukowej, red. H. Dzwonkowski, J. Głuchowski, A. Pomorska, J. Szołno-Koguc, Lublin 2005.

Grabowski P., Herman M., O normatywnym charakterze przepisów o wejściu w życie, Państwo i Prawo 2006, z. 9.

Grabowski P.J., W sprawie zakresu temporalnego obowiązywania prawa, Państwo i Prawo 2004, z. 4.

Gray H.L., Carlton v. United States: An Analysis of Retroactive Tax Legislation, Stetson Law Review 1995, t. 24, nr 3.

Gwiazdomorski J., Międzyczasowe prawo prywatne, Nowe Prawo 1965, nr 6.

Heron J., Principes du droit transitoire, Dalloz 1996.

Huchla A., Nieprzestrzeganie "zasad podatkowych" w procesie tworzenia polskiego prawa podatkowego, w: Prawo finansowe i nauka prawa finansowego na przełomie wieków, red. A. Kostecki, Kraków 2000.

Jakimowicz W., Kilka uwag na temat metody regulacji intertemporalnej w kontekście sytuacji prawnej jednostki, w: Administracja publiczna pod rzadami prawa. Ksiega pamiatkowa z okazji 70-lecia urodzin prof. zw. dra hab. Adama Błasia, red. J. Korczak, Wrocław 2016 [online], https:/ / repozytorium.uni.wroc.pl/dlibra/publication/82612/edition/79094/content [dostęp: 25.01.2020 r.].

Jakimowicz W., Publiczne prawa podmiotowe, Kraków 2002.

Kaleda S.L., Przejęcie prawa wspólnotowego przez nowe państwo członkowskie. Zagadnienia przejściowe oraz międzyczasowe, Warszawa 2003.

Kamiński M., Prawo administracyjne intertemporalne, Warszawa 2011.

Karasiewicz K., w: Prawo intertemporalne w orzecznictwie Trybunatu Konstytucyjnego i Sądu Najwyższego, red. E. Łętowska, K. Osajda, Warszawa 2008.

Kłoda M., Prawo międzyczasowe prywatne. Podstawowe zasady, Warszawa 2007.

Kłoda M., Wybrane zagadnienia intertemporalne Kodeksu spótek handlowych. Cz. I, Monitor Prawniczy 2001, nr 8.

Kościół wobec wspótczesnych problemów życia gospodarczego. Społeczne dokumenty episkopatów, red. S. Fel, J. Kupny, Lublin 2002.

Kozerska E., Państwo i społeczeństwo w pogląach Piusa XI, Wrocław 2005. 
Kurowska P., Problemy intertemporalne w aspekcie tworzenia prawa podatkowego, Kwartalnik Prawa Podatkowego 2005, nr 2.

Laitos J.G., Legislative Retroactivity, Urban Law Annual; Journal of Urban and Contemporary Law 1997, t. 52.

Lang W., Obowiązywanie normy prawnej w czasie w świetle logiki norm, Zeszyty Naukowe Uniwersytetu Jagiellońskiego. Prace Prawnicze 1960, z. 7.

Łączkowski W., Wymiar sprawiedliwości a stosowanie prawa, w: Ius et lex. Księga jubileuszowa ku czci Profesora Adama Strzembosza, red. A. Dębiński, A. Grześkowiak, K. Wiak, Lublin 2002.

Łętowska E., Polityczne aspekty prawa intertemporalnego, w: Państwo. Prawo. Obywatel. Zbiór studiów dla uczczenia 60-lecia urodzin i 40-lecia pracy naukowej prof. Adama Łopatki, red. J. Łętowski, W. Sokolewicz, Wrocław 1989.

Łętowska E., w: Prawo intertemporalne w orzecznictwie Trybunatu Konstytucyjnego i Sądu Najwyższego, red. E. Eętowska, K. Osajda, Warszawa 2008.

Małecki J., Kwestie intertemporalne w prawie podatkowym, w: Regulacje prawno-podatkowe i rozwiazania finansowe Pro publico bono. Ksiegga Jubileuszowa Profesora Jana Głuchowskiego, red. J. Głuchowski, Toruń 2002.

Mikołajewicz J., Prawo intertemporalne. Zagadnienia teoretycznoprawne, Poznań 2000.

Morawski L., Wstęp do prawoznawstwa, Torun 2002.

Mordwiłko J., Osajda K., w: Prawo intertemporalne w orzecznictwie Trybunatu Konstytucyjnego i Sądu Najwyższego, red. E. Łętowska, K. Osajda, Warszawa 2008.

Nita B., Światłowski A., O retroaktywności prawa karnego (uwagi polemiczne na tle artykułu W. Wróbla), Przegląd Sądowy 1994, nr 3.

Nowacki J., Kryteria obowiazywania norm prawnych a wytyczne wymiaru sprawiedliwości i praktyki sądowej, Studia Prawno-Ekonomiczne 1974, t. 13.

Osajda K., Znaczenie zasad prawnych dla wykładni prawa (na przykładzie prawa cywilnego), w: Teoria i praktyka wykładni prawa, red. P. Winczorek, Warszawa 2005.

Pałecki K., O zjawisku dylatacji mocy obowiąujacej prawa, w: Prawo $i$ ład społeczny. Księga Jubileuszowa dedykowana Profesor Annie Turskiej, red. G. Polkowska, Warszawa 2000.

Pietrzykowski T., Temporalny zakres obowiązywania prawa, Państwo i Prawo 2003, z. 4 .

Pietrzykowski T., Wsteczne działanie prawa i jego zakaz, Kraków 2004.

Problematyka intertemporalna w prawie. Zagadnienia podstawowe. Rozstrzygnięcia intertemporalne. Geneza i funkcje, red. J. Mikołajewicz, Warszawa 2015.

Radwański Z., Zarys części ogólnej prawa cywilnego, Warszawa 1981.

Radziewicz P., Umarzanie postepowania przez Trybunat Konstytucyjny ze wzgledu na utrate mocy obowiązujacej przepisu przed wydaniem orzeczenia, Przegląd Sejmowy 2006, nr 2.

Rot H., Elementy teorii prawa, Wrocław 1994. 
Roubier P., Le Droit Transitoire (conflits des lois dans le temps), Paris 1960.

Smith B., Retroactive Laws and Vested Rights, Texas Law Review 1927, t. 5.

Smolak M., Uzasadnienie sadowe jako argumentacja z moralności politycznej. O legitymizacji władzy sędziowskiej, Kraków 2003.

Sośniak M., Konflikty w czasie norm cywilnoprawnych, Kraków 1962, Zeszyty Naukowe Uniwersytetu Jagiellońskiego, t. 48.

Stelmach J., Obowiazywanie prawa w sensie absolutnym i relatywnym, w: Teoria prawa. Filozofia prawa. Wspótczesne prawo i prawoznawstwo, red. M. Kocoł, W. Lang, Toruń 1998.

System prawa cywilnego, t. 1. Część ogólna, red. S. Grzybowski, Wrocław 1985.

Tuleja P., Stosowanie Konstytucji RP w świetle zasady jej nadrzędności (wybrane problemy), Kraków 2003.

Wiemeyer J., Podatki jako problem etyczno-społeczny, w: Katolicka nauka społeczna. Podstawowe zagadnienia z życia gospodarczego, J. Kupny, S. Fel, Katowice 2003.

Wronkowska S., O stanowieniu i ogłaszaniu prawa oraz kulturze prawnej, Państwo i Prawo 2007, z. 4.

Wronkowska S., O źródłach prawa i aktach normatywnych raz jeszcze, w: Prawo prywatne czasu przemian. Ksiegga pamiątkowa dedykowana Profesorowi Stanistawowi Sołtysińskiemu, red. A. Nowicka, Poznań 2005.

Wróbel W., Zmiana normatywna i zasady intertemporalne w prawie karnym, Kraków 2003.

Wróblewski J., Sądowe stosownie prawa, Warszawa 1988.

Wyrzykowski M., Zasada demokratycznego państwa prawnego, w: Zasady podstawowe polskiej Konstytucji, red. W. Sokolewicz, Warszawa 1998.

Ziembiński Z., Teoria prawa, Warszawa-Poznań 1973.

Zirk-Sadowski M., Problem nowości normatywnej, Studia Prawno-Ekonomiczne 1979 , t. 22.

Zwoliński A., Katolik i pieniądze, Częstochowa 2007.

\section{Streszczenie}

Przedmiotem rozważań jest ukazanie wybranych aspektów intertemporalnego prawa podatkowego, istotnych z punktu widzenia podstawowych wskazań społecznej nauki Kościoła katolickiego. Chodzi o konfrontację wybranych zasad obecnych w obu tych dziedzinach. Zaniechanie troski o etyczne umocowanie prawa, również w omawianym zakresie, może naruszać bowiem godność podatników. Antidotum na tego rodzaju niebezpieczeństwa stanowi przestrzeganie reguł stanowienia prawa z uwzględnieniem zasad: personalizmu, dobra wspólnego, solidarności, sprawiedliwości i pomocniczości, obecnych w nauce 
społecznej Kościoła katolickiego. Na gruncie polskiego systemu prawnego pewna część reguł realizowanych w ramach tych zasad objęta jest prawną definicją demokratycznego państwa prawa. Ponadto powszechnie znaną granicą aktywności ustawodawczej jest np. zakaz tworzenia prawa działającego wstecz, obowiązek zachowania odpowiedniej vacatio legis, zakaz skrajnego przerostu regulacji. Rzeczywiste respektowanie osobowej wizji człowieka musi skutkować szacunkiem poszczególnych ludzi i instytucji do podejmowanych przez człowieka aktywności (prawa nabyte) i czynionych przez niego planów (interesy w toku). Dobro wspólne i pozostałe zasady katolickiej nauki społecznej winny stale być wezwaniem do większej miłości i zrozumienia sytuacji współobywateli. Z kolei wielkoduszność wobec drugiego człowieka pomaga dostrzec solidarnościowy charakter danin publicznych. Wpisuje się to w konieczność pokornego uznania wzajemnej zależności ludzi oraz ich współodpowiedzialności, w tym za siebie wzajemnie przed Bogiem.

Słowa kluczowe: podatkowe przepisy intertemporalne, katolicka nauka społeczna, lex retro non agit, vacatio legis, prawa nabyte

\section{SELECTED INTERTEMPORAL PROBLEMS IN THE TAX LAW WITHIN THE CONTEXT OF INDICATIONS OF CATHOLIC SOCIAL THOUGHT}

\section{Sum mary}

The subject of deliberations in this article focuses on the presentation of selected aspects of intertemporal tax law, relevant from the point of view of the basic indications of social teaching of the Catholic Church. Failure to care for the ethical legitimacy of the law may violate the dignity of taxpayers. The antidote to this kind of danger is compliance with the rules of lawmaking, taking into account the principles of: personalism, common good, solidarity, justice and subsidiarity, present in the social teaching of the Catholic Church. On the basis of the Polish legal system, a part of the rules implemented under these principles is covered by the legal definition of a democratic state of law. In addition, a well-known limit of legislative activity is, for example, the prohibition of the creation of retroactively applicable law, the obligation to maintain adequate vacation legis, prohibition of over-regulation and their instability. The actual respect of one's personal vision must result in respect for individual people and for the institutions of human activities (the acquired rights) and for plans made by them (interests in progress). The common good and other CST principles should always be a call for greater lob and understanding of the situation of fellow citizens. In turn, magnanimity towards another man helps to see the solidarity of public tributes. This fits in with 
the necessity of humbly acknowledging the independence of people and their joint responsibility towards God.

Key words: tax intertemporal regulations, Catholic Social Teaching, lex retro non agit, vacation legis, acquired rights

\section{ИЗБРАННЫЕ ИНТЕРТЕМПОРАЛЬНЫЕ ПРОБЛЕМЫ НАЛОГОВОГО ПРАВА В КОНТЕКСТЕ УКАЗАНИЙ СОЦИАЛЬНОГО УЧЕНИЯ КАТОЛИЧЕСКОЙ ЦЕРКВИ}

\section{Резюме}

Предметом обсуждения является демонстрация отдельных аспектов $u$ тертемпорального налогового законодательства, актуальных с точки зрения основных принципов социального учения Католической церкви. Повествуется о противостоянии отдельных принципов, присутствующих в обеих этих областях. Несоблюдение этической стороны права, также по отношении к налоговому законодательству, может нарушить достоинство налогоплательщиков. Противоядием от такого рода опасностей является соблюдение норм законотворчества, включая принципы персонализма, общего блага, солидарности, справедливости и субсидиарности, которые присутствуют в социальном учении Католической церкви. В польской правовой системе некоторые правила, применяемые в соответствии с этими принципами, охватываются правовым определением демократического правового государства. Кроме того, общеизвестным ограничением законодательной деятельности являются, например, запрет на создание ретроактивного закона, обязательство учитывать адекватное vacatio legis, запрет на чрезмерное регулирование. Истинное уважение к личностному образу человека как такового, должно привести к уважению отдельных людей и учреждений, уважению к действиям, предпринимаемым ими (приобретенные права), и планам, которые они осуществляют (интересы в процессе). Общее благо и другие принципы католического социального обучения должны постоянно быть призывом к большей любви и пониманию ситуации сограждан. В свою очередь, щедрость по отношению к другим людям помогает признать характер общественных сборов в ключе принципа солидарности. Это связано непосредственно с необходимостью смиренно признать взаимную зависимость людей и их общую ответственность, в том числе друг перед другом, перед Богом.

Ключевые слова: интертемпоральное налоговое регулирование, социальное учение Католической церкви, lex retro non agit, vacatio legis, приобретенные права 